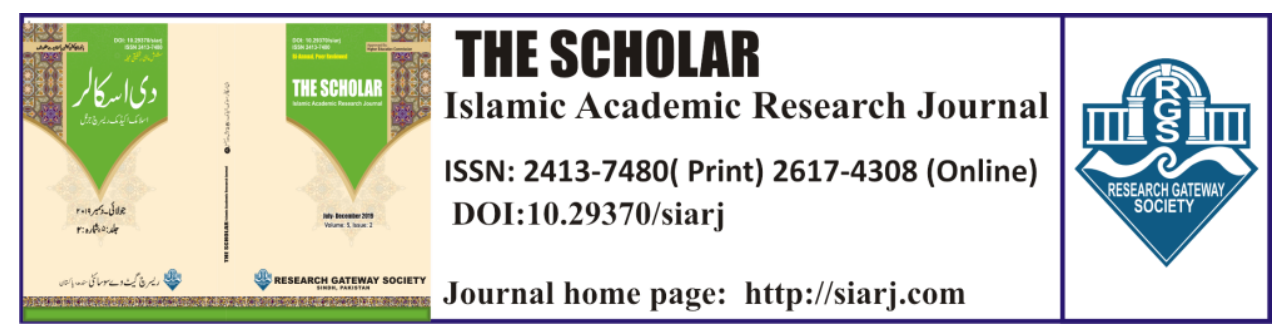

\title{
BACK TO FUNDAMENTALS: IS ETHICAL LEADERSHIP SUFFICIENT OR WE ALSO NEED ISLAMIC WORK ETHICS TO KEEP EMPLOYEES PERFORMING?
}

\section{Anjeela Khurram}

PhD Scholar, RITM University of Paris Sud (Saclay) Paris, France.

Email: anjeela.haroon@u-psud.fr

ORCID ID:

https://orcid.org/0000-0001-5006-6057x

\section{Dr. Seerat Fatima}

Assistant Professor, Bahaudin Zakriya University Multan, Pakistan. Email: seeratfatima@bzu.edu.pk ORCID ID: https://orcid.org/0000-0002-5502-366X

\section{Dr. Shahzad Khurram}

Assistant Professor, Air University School of Management Islamabad, Pakistan.

Email: khurramjah2002@yahoo.co.uk

ORCIID IID:

https://orcid.org/0000-0002-1364-0942x

To cite this article:

Khurram, Anjeela, Seerat Fatima and Shahzad Khurram. "BACK TO FUNDAMENTALS: IS ETHICAL LEADERSHIP SUFFICIENT OR WE ALSO NEED ISLAMIC WORK ETHICS TO KEEP EMPLOYEES PERFORMING?" The Scholar-Islamic Academic Research Journal 6, No. 1 (March 26, 2020): 1-23.

To link to this article: https://doi.org/10.29370/siarj/issue10ar1

Journal

Publisher

DOI:

URL:

License:

Journal homepage

Published online:
The Scholar Islamic Academic Research Journal

Vol. 6, No. 1 ||January-June 2020 || P. 1-23

Research Gateway Society

10.29370/siari/issue10ar1

https://doi.org/10.29370/siari/issue10ar1

Copyright c 2017 NC-SA 4.0

www.siari.com

2020-26-03
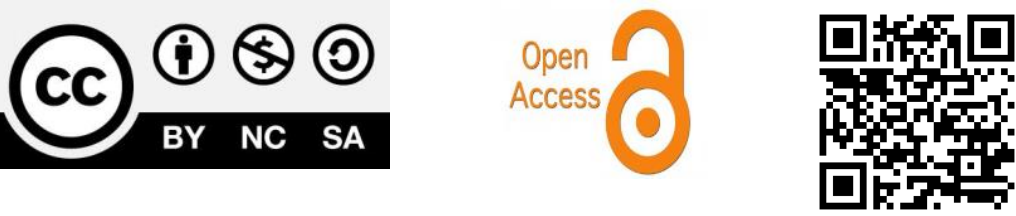


\title{
BACK TO FUNDAMENTALS: IS ETHICAL LEADERSHIP SUFFICIENT OR WE ALSO NEED ISLAMIC WORK ETHICS TO KEEP EMPLOYEES PERFORMING?
}

Anjeela Khurram, Seerat Fatima, Shahzad Khurram

\begin{abstract}
:
This study aims to investigate the impact of ethical leadership on job performance, organizational citizenship behavior and turnover Intention. Importantly, it examines the moderating role of Islamic work ethics. In this survey research participants were 350 employees randomly selected from telecom sector. Results indicate that ethical leadership is associated with increase in Job Performance Organizational citizenship behavior and decrease in employee's turnover intention. Moreover, the results show that Islamic work ethics moderate the relationship between ethical leadership and job performance. This study was limited to the telecom sector of Pakistan. A predictive model on ethical leadership \& Islamic work ethics could be built involving multiple sectors and geographical areas to gain higher generalizability. Our research suggests that telecom sector should develop and institute high ethics human resource practices that involve ethical recruitment and selection, training and compensation activities. These findings will contribute to the growing literature on Islamic work ethics and ethical leadership.
\end{abstract}

KEYWORDS: Ethical Leadership, Islamic work ethics, Job performance, Organizational citizenship behavior, Turnover Intention. 


\section{INTRODUCTION:}

Both the governments \& private organizations are facing variety of leadership related challenges. One proven solution to such challenges is ethical leadership that ensures long term success of the organization by achieving positive work outcomes. In response to emotions treated ethically by their leader, followers are expected to respond with positive work behaviors (in line with social exchange theory; ${ }^{1}$. Therefore, increased attention is being paid to the role of ethical leadership ${ }^{2}$ in fostering cooperative attitudes and behaviors among employees.

In our study we empirically examined the relationship of ethical leadership with job performance, organizational citizenship behavior and turnover intention in telecommunication sector of Pakistan-a context that has remained understudied. We have deliberately chosen the Telecommunication sector of Pakistan to assess these relationships. This sector has emerged as a key driver of Pakistan's economy growth. This sector employs around 1.36 Million individuals and its subscribers have exponentially grown to 137.09 million in 2017 , from merely 0.3 million in 2000. Likewise, the total tele-density has remarkably grown from $4.31 \%$ in 2002-03 to $71.66 \%$ in 2017 (Telecom Indicators, 2017). Therefore, Telecommunication sector of Pakistan offers a unique research site where relationships of ethical leadership with job performance, organizational citizenship behavior and turnover intention is examined in a specific

\footnotetext{
1 Peter Michael Blau, "Social Exchange Theory," in The SAGE Encyclopedia of Corporate Reputation, 1964, https://doi.org/10.4135/9781483376493.n287.

${ }^{2}$ Michael E. Brown and Linda K. Treviño, "Ethical Leadership: A Review and Future Directions," Leadership Quarterly 17, no. 6 (2006): 595-616, https://doi.org/10.1016/j.leaqua.2006.10.004.
} 
situation when organizations and sector is undergoing a gigantic growth and take overs. Certainly, such an environment with enormous growth cannot be called normal and stable and is different from research sites studied earlier.

With the growing complexity of telecommunication organizations in Pakistan and the expanding influence of number of internal and external stakeholders, there is a need to examine the ethical context of these organizations as well. When it comes to ethical contexts, Islamic work ethics has been a topic of interest for researchers during recent years. Islamic work ethics have been found to have significant impact on employees' attitudes and behaviors ${ }^{3}$. A careful review of extant literature suggests that only handful of studies presented the moderating role of Islamic work ethics on relationship between ethical leadership and job outcomes ${ }^{4}$. More importantly, such relationships have not been examined in a high growth organizational environment ${ }^{5}$. This research paper fills this gap and examines the impact of ethical leadership on job performance, organization citizenship behavior and turn-over intention with moderating role of Islamic Work ethics.

\footnotetext{
${ }^{3}$ Ronald F. Piccolo et al., "The Relationship between Ethical Leadership and Core Job Characteristics," Journal of Organizational Behavior 31, no. 2-3 (February 1, 2010): 259-78, https://doi.org/10.1002/job.627.

${ }^{4}$ Syeda Madiha Kanwal Batool, Asma Gul, and Khurram Shahzad, "Combined Effects of Ethical Leadership and Islamic Work Ethics ( IWE ) on Organizational Commitment and Job Satisfaction," Journal of Islamic Business and Management 3, no. 1 (June 2013): 3550, https://doi.org/10.12816/0004987.

5 Darwis Saban et al., "Impact Of Islamic Work Ethics, Competencies, Compensation, Work Culture On Job Satisfaction And Employee Performance: The Case Of Four Star Hotels," European Journal of Business and Management Research 5, no. 1 (2020), https://doi.org/10.24018/ejbmr.2020.5.1.181.
} 
Our work is formatted as follows: In section 2 we present a thorough review of literature. In section 3, detailed methodology is given including sample of study and measurement instruments etc. In next section, we present analysis and results and finally in section 5, we provide discussion and conclusion.

\section{$2.1 \quad$ ETHICAL LEADERSHIP}

Leadership is a persuasive process which contributes in the success of the organization ${ }^{6}$. There are different leadership styles and one prominent one is ethical leadership style ${ }^{7}$. Ethical leaders are good-hearted, true, honest, trustworthy and ethical decision-makers who care about the well-being of their followers and broader society ${ }^{8}$. Ethical leadership is the demonstration of normatively appropriate conduct through personal actions and interpersonal relationships, and the promotion of such conduct to followers through two-way communication, reinforcement and decision-making. In line with the previous research, Brown et al. suggest that ethical leaders are not only the moral managers but they should be moral supporters as well.

\subsection{Ethical Leadership and Job Performance}

Job performance is defined as "the level of productivity of an individual employee, relative to his or her peers, on several job-related behaviors and

\footnotetext{
${ }^{6}$ Gary Yukl, Angela Gordon, and Tom Taber, "A Hierarchical Taxonomy of Leadership Behavior: Integrating a Half Century of Behavior Research," Journal of Leadership \& Organizational Studies 9, no. 1 (August 14, 2002): 15-32, https://doi.org/10.1177/107179190200900102.

${ }^{7}$ Yukl, Gordon, and Taber.

${ }^{8}$ Brown and Treviño, "Ethical Leadership: A Review and Future Directions."
} 
outcomes" 9 .

Ethical leadership has been proposed to influence employee Performance as employees are motivated to work for their organization ${ }^{10}$. If followers perceive ethical behavior from top management, they are more willing to perform for the organization. On the other hand, if leadership is perceived unethical, employees will avoid taking responsibility and get disheartened to perform ${ }^{11}$. Ethical leadership generates trust and commitment of employees, which in turn gives long term performance to the organization. Ethical leader helps to give meaning to their employees and ensures that employees' decisions and performance are according to the requirements (See Figure 1). Therefore, we hypothesize that: H1: Ethical Leadership has a positive impact on employees' Job Performance.

\subsection{Ethical Leadership and Organizational citizenship Behavior}

Employee's attitudes and behaviors which are result of leader's capability can be measured through variety of factors such as employee's job performance, job involvement, job satisfaction, organizational citizenship behavior and organizational commitment ${ }^{12}$. It has been suggested that these outcomes might be enhanced by adopting the ethical leadership

\footnotetext{
${ }^{9}$ Barry J. Babin and James S. Boles, "Employee Behavior in a Service Environment: A Model and Test of Potential Differences between Men and Women," Journal of $\begin{array}{llllll}\text { Marketing } & 62, & \text { no. } & 2 & \text { (April 19, } & \text { 77-91, }\end{array}$ https://doi.org/10.1177/002224299806200206.

10 Piccolo et al., "The Relationship between Ethical Leadership and Core Job Characteristics."

${ }^{11}$ Wendy O'Connell and Michelle Bligh, "Emerging from Ethical Scandal: Can Corruption Really Have a Happy Ending?," Leadership 5, no. 2 (May 1, 2009): 213-35, https://doi.org/10.1177/1742715009102935.

12 MAY McShane, Steven L and Von Glinow, "Workplace Emotions, Attitudes, and Stress," Organizational Behavior, 2010.
} 
style $^{13}$. Ethical leaders establish and encourage ethical standards. Ethical leadership boosts positive behavior and discourages misbehavior, thus supporting an environment that is favorable to organizational citizenship behavior.

Ethical leader establishes ethical standards and encourage others to apply these ethics in organization and reinforce positive behavior such as organization citizenship behavior. According to Organ, organizational citizenship behavior is defined as "individual behavior that is discretionary, not directly or explicitly recognized by the formal reward system, and in the aggregate promotes the effective functioning of the organization" $^{14}$ (p.4). It has been suggested that there might be positive relationship between ethical leadership \& organization citizenship behavior ${ }^{15}$. Ethical Leader initiates ethical principles and provide guidelines to employees which might create the environment of organizational citizenship behavior. Therefore, we hypothesize on these grounds that:

\section{H2: Ethical Leadership has a positive impact on employees' Organizational citizenship behavior.}

\footnotetext{
${ }^{13}$ Brown and Treviño, "Ethical Leadership: A Review and Future Directions"; David M Mayer, Maribeth Kuenzi, and Rebecca L Greenbaum, "Examining the Link Between Ethical Leadership and Employee Misconduct :," Journal of Business Ethics 95 (2011): 7-16, https://doi.org/10.1007/s10551-011-0794-0.

14 Dennis W. Organ, “Organizational Citizenship Behavior: It's Construct Clean-up Time," Human Performance 10, no. 2 (1997): 85-97, https://doi.org/10.1207/s15327043hup1002_2.

15 Nathan P. Podsakoff et al., "Individual- and Organizational-Level Consequences of Organizational Citizenship Behaviors: A Meta-Analysis," Journal of Applied Psychology 94, no. 1 (January 2009): 122-41, https://doi.org/10.1037/a0013079.
} 
Back to fundamentals: is ethical leadership sufficient or we also need Islamic work ethics to keep employees performing?

\subsection{Ethical Leadership and Turnover Intention}

Employee's turnover is a major challenge and threat for the organizations ${ }^{16}$. Turnover is defined as voluntarily leaving the job and the process by which an employee is willing to terminate their membership with the organization ${ }^{17}$. Turnover intention is a cognitive process of thinking, planning, and desiring to quit the job ${ }^{18}$. There is a strong bond between ethical leaders and employees which creates a delightful environment at work to increase commitment and decrease turnover intention. Firth et al. ${ }^{19}$ suggested that turnover intentions are influenced by behavior of leaders. These authors assert that leadership behaviors affect the job performance and decrease the turnover intentions of the employees. When employees receive a sense of satisfaction from their jobs through ethical conduct, they show a favorable attitude toward their workplace and ultimately, these employees have lower intention to quit. Therefore, ethical dimensions of the leadership are important because leaders influence the behavior of employees. Ethical leaders may play a vital role $\&$ promote ethical behavior among the subordinates to decrease the intention to leave the job ${ }^{20}$. In view of this we hypothesize that:

16 Rodger W. Griffeth, Peter W. Hom, and Stefan Gaertner, "A Meta-Analysis of Antecedents and Correlates of Employee Turnover: Update, Moderator Tests, and Research Implications for the Next Millennium," Journal of Management 26, no. 3 (June 1, 2000): 463-88, https://doi.org/10.1177/014920630002600305.

${ }^{17}$ Griffeth, Hom, and Gaertner.

${ }^{18}$ William H. Mobley, Stanley O. Horner, and A. T. Hollingsworth, "An Evaluation of Precursors of Hospital Employee Turnover," Journal of Applied Psychology 63, no. 4 (1978): 408-14, https://doi.org/10.1037/0021-9010.63.4.408.

${ }^{19}$ Lucy Firth et al., "How Can Managers Reduce Employee Intention to Quit?," Journal of Managerial Psychology 19, no. 2 (2004): $170-87$, https://doi.org/10.1108/02683940410526127.

${ }^{20}$ Brown and Treviño, "Ethical Leadership: A Review and Future Directions." 
Back to fundamentals: is ethical leadership sufficient or we also need Islamic work ethics to keep employees performing?

H3: Ethical Leadership has a negative impact on employees' Turnover intention.

\subsection{Islamic Work Ethics}

Ethics give a clear description of right and wrong conduct. Weber's theory of protestant work ethics has made ethics an important and integral part of a work setting. Ali ${ }^{21}$ gave the concept of Islamic work ethics by defining that Islamic ethical values influence the business world and organizational performance. It has been shown that Islamic work ethics positively influence employee performance, satisfaction and commitment levels ${ }^{22}$. Islamic work ethics are also found to be a moderator between job satisfaction and organizational commitment in a study conducted by Yousef ${ }^{23}$. Many researchers conducted study on Islamic work ethics and concluded that they are closely related to job outcomes ${ }^{24}$. To find out the methods and approaches for increasing employee performance and interest in work, it is necessary to understand the association between Islamic

21 Abbas J. Ali, "The Islamic Work Ethic in Arabia," Journal of Psychology: Interdisciplinary and Applied 126, no. 5 (1992): 507-19, https://doi.org/10.1080/00223980.1992.10543384.

${ }^{22}$ Abdus Sattar Abbasi, Kashif Ur Rehman, and Amna Bibi, "Islamic Work Ethics: How It Affects Business Performance," Actual Problems of Economics 126, no. 12 (2011): 312-22, https://papers.ssrn.com/sol3/papers.cfm?abstract_id=1992008; Wahibur Rokhman, "The Effect of Islamic Work Ethics on Work Outcomes," Electronic Journal of Business Ethics and Organization Studies, vol. 15, 2010, http://ejbo.jyu.fi/.

${ }^{23}$ Darwish A. Yousef, "Islamic Work Ethic: A Moderator between Organizational Commitment and Job Satisfaction in a Cross-Cultural Context," Personnel Review 30, no. 2 (2001): 152-69, https://doi.org/10.1108/00483480110380325.

${ }^{24}$ Maaz Ud Din et al., "EFFECT OF ISLAMIC WORK ETHICS ON JOB PERFORMANCE: MEDIATING ROLE OF INTRINSIC MOTIVATION," IJIBE (International Journal of Islamic Business Ethics 4, no. 2 (2019), https://doi.org/10.30659/ijibe.4.2.676-688. 
Back to fundamentals: is ethical leadership sufficient or we also need Islamic work ethics to keep employees performing?

work ethics and job outcomes so that actionable strategies are devised that may help in reducing the factors that lead to undesirable outcomes ${ }^{25}$.

Fig 1: Model of the Study

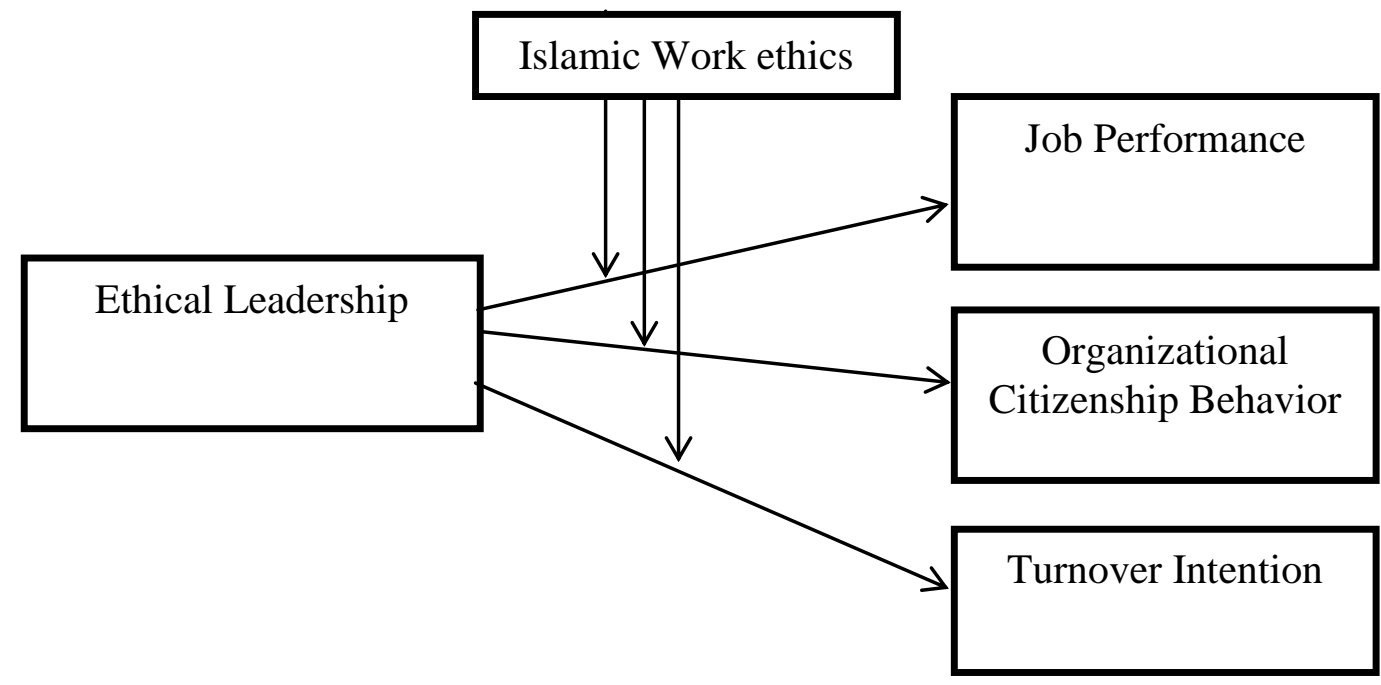

\subsection{Moderating Role of Islamic work ethics}

Ethics play very important role in constructing the behavior of a person at work place ${ }^{26}$. Extant research has to some extent examined the moderating role of Islamic work ethics on relationship between job satisfaction and job commitment. However, combined effect of ethical

\footnotetext{
${ }^{25}$ Yousef, "Islamic Work Ethic: A Moderator between Organizational Commitment and Job Satisfaction in a Cross-Cultural Context."

${ }^{26}$ Iraj Mahdavi, "Where Do Men and Women Learn Their Ethics? Different Sources?," Journal of Academic and Business Ethics 1 (2009): 1-7, http://search.proquest.com/docview/759567263?accountid=14549\%5Cnhttp://hl5yy6xn2 p.search.serialssolutions.com/?genre=article\&sid=ProQ: \&atitle=WHERE+DO+MEN+A ND+WOMEN+LEARN+THEIR+ETHICS?+DIFFERENT+SOURCES?\&title=Journal+ of+Academic+and+Business+Ethics\&issn=.
} 
Back to fundamentals: is ethical leadership sufficient or we also need Islamic work ethics to keep employees performing?

\begin{tabular}{lccc}
\hline Table 1: Sampling Characteristics & & \\
\hline Gender & Male & Frequency & Percentage \\
\multicolumn{1}{l}{ Age } & Female & 183 & $52 \%$ \\
& 25 and below & 167 & $48 \%$ \\
& $26-35$ & & \\
& $36-45$ & 108 & 30.9 \\
& $46-55$ & 185 & $53 \%$ \\
& 55 and above & 42 & $12 \%$ \\
Education & & 11 & $3 \%$ \\
& Bachelors & 4 & $1 \%$ \\
& Masters & & $31 \%$ \\
& MS & 107 & $42 \%$ \\
& Doctoral & 146 & $25 \%$ \\
\hline Designation & & 89 & $2 \%$ \\
& Managerial & 8 & $67 \%$ \\
& Non Managerial & 233 & $33 \%$ \\
\hline
\end{tabular}

leadership and Islamic work ethics may provide insights as employees may feel more committed to the job ${ }^{27}$. Several other studies reported moderating effect of Islamic work ethics on variety of variables' relationships e.g., -- organizational justice, turnover intention, organizational commitment, job satisfaction and job stress etc. ${ }^{28}$

${ }^{27}$ Batool, Gul, and Shahzad, "Combined Effects of Ethical Leadership and Islamic Work Ethics ( IWE ) on Organizational Commitment and Job Satisfaction.”

28 Abdul Shukor Shamsudin, Hamzah Abdul Rahman, and A. Rahim Romle, "The Moderating of Islamic Work Ethic on Relationship of Emotional Intelligence and Leadership Practice: A Proposed Framework," International Journal of Innovation, Management and Technology 6, no. 2 (2015): 140-43, https://doi.org/10.7763/ijimt.2015.v6.591. 
The Scholar Islamic Academic Research Journal

Vol. 6, No. 1 || January -June 2020 || P. 1-23

https://doi.org/10.29370/siarj/issue10ar1

A lot has been suggested regarding the moderating effect of IWE involving various variables, however, the moderating effect of IWE between ethical leadership and job outcomes has not been fully examined. Therefore, we suggest that this moderating effect should be investigated through following hypotheses

H4: IWE moderates the relationship between ethical leadership \& Job performance in a way that positive relationship between $E L \& J P$ will be stronger when IWE will be high.

H5: IWE moderates the relationship between ethical leadership \& Organization Citizenship Behavior in a way that positive relationship between EL \& OCB will be stronger when IWE will be high.

H6: IWE moderates the relationship between ethical leadership \& Turnover Intention in a way that negative relationship between EL \& TI will be stronger when IWE will be high.

\section{Methodology}

\subsection{Sample}

The population frame comprises of the employees from eight telecom organizations (Telenor, Zong, PTCL, Wateen, Witribe, Warid, Mobilink and Ufone) (See Table 1). Simple random sampling technique for data collection has been used so as to achieve high generalizability. Due to the limited resources at the disposal of scholars, questionnaires were sent to respondents by post and by e-mail. Approximately 453 survey questionnaires written in English have been distributed for collection of data and 350 were returned; full and complete (Response rates was approximately $78 \%)$. 
The Scholar Islamic Academic Research Journal

Vol. 6, No. 1 || January -June 2020 || P. 1-23

https://doi.org/10.29370/siarj/issue10ar1

\subsection{Measurement}

The variables of the study were examined by using a five point Likert-scale ranging from strongly disagree (1) to strongly agree (5) to strongly disagree (See Table 2).

Table 2: Summary of Scales

\begin{tabular}{llc} 
Variable & Author of the Scale & No. of items \\
Ethical Leadership & $\begin{array}{l}\text { Brown, M. E., Treviño, L. } \\
\text { K., \& Harrison, D. A. }\end{array}$ & 10 \\
Job Performance & $\begin{array}{l}\text { Teseema \& Soeters (2006) } \\
\text { Bozeman \& Perrewe }\end{array}$ & 4 \\
Organizational & $\begin{array}{l}\text { (2001) } \\
\text { Citizenship Behavior }\end{array}$ & 16 \\
Turnover Intention & Hellgren et al. (1997) & 3 \\
Islamic Work Ethics & Ali (1988) & 17 \\
\hline
\end{tabular}

\subsubsection{Ethical Leadership}

Brown et al.'s (2005) 10 items scale was used to measure ethical leadership. The sample items include "I discussed business ethics or values with employees". In our study, Cronbach's alpha of the scale was 0.948, representing good measurement reliability.

\subsubsection{Organizational Citizenship Behavior}


The Scholar Islamic Academic Research Journal

Vol. 6, No. 1 || January -June 2020 || P. 1-23

https://doi.org/10.29370/siarj/issue10ar1

$\overline{\text { Bozeman \& Perrewe }{ }^{29} 16 \text { items scale was used to measure organizational }}$ citizenship behavior of employees'. The sample items include the items like "I attend and actively participate in organizations meetings" and "I consume a lot of time complaining about trivial matters" (Reverse item (R)). Scale item number 8, 9, 10, 11 were reversed. Cronbach's alpha of Organizational Citizenship Behavior scale was 0.764 representing satisfactory measuring reliability (Please See Table 3).

Table 3: Reliability Statistics

\begin{tabular}{lcccc}
\hline Variables & $\begin{array}{c}\text { No. Of } \\
\text { Items }\end{array}$ & $\begin{array}{c}\text { Cronbach's } \\
\text { Alpha }\end{array}$ & $\begin{array}{c}\text { Cronbach's Alpha } \\
\text { If item deleted }\end{array}$ \\
\hline $\begin{array}{l}\text { Ethical Leadership } \\
\text { Job Performance }\end{array}$ & 10 & 0.948 & - & $\begin{array}{c}\text { No item } \\
\text { deleted }\end{array}$ \\
Organizational & 4 & 0.719 & & \\
Citizenship & 16 & 0.764 & & \\
Behaviour & 3 & & & \\
Turnover Intention & 17 & 0.986 & \\
Islamic Work Ethics & & 0.918 & \\
\hline
\end{tabular}

\subsubsection{Islamic Work Ethics}

17 items scale developed by Ali is used to assess Islamic Work Ethics. The items of scale include "Laziness is a vice" and "Dedication to work is a virtue" amongst others. Cronbach's alpha of Islamic Work Ethics scale was 0.918, representing satisfactory reliability.

\footnotetext{
${ }^{29}$ Dennis P. Bozeman and Pamela L Perrewé, "The Effect of Item Content Overlap on Organizational Commitment Questionnaire-Turnover Cognitions Relationships," Journal of Applied Psychology 86, no. 1 (2001): 161-73, https://doi.org/10.1037/00219010.86.1.161.
} 
The Scholar Islamic Academic Research Journal

Vol. 6, No. 1 || January -June 2020 || P. 1-23

https://doi.org/10.29370/siarj/issue10ar1

\subsubsection{Job Performance}

Four items scale was used to measure job performance developed by Teseema \& Soeters ${ }^{30}$. The sample items include "My performance is better than that of my colleagues with similar qualifications". Cronbach's alpha of the scale was 0.719 , representing satisfactory reliability (Please See Table 3).

\section{Table 4: Correlations}

\begin{tabular}{|c|c|c|c|c|c|c|}
\hline & & $\mathbf{J P}$ & TI & OCB & IWE & EL \\
\hline \multirow{3}{*}{$\mathbf{J P}$} & Pearson Correlation & 1 & .036 & -.045 & $.144^{* *}$ & $.130^{*}$ \\
\hline & Sig. & & .498 & .398 & .007 & .015 \\
\hline & Pearson Correlation & .036 & 1 & -.103 & $-.243^{* *}$ & $-.243^{* *}$ \\
\hline \multirow[t]{2}{*}{ TI } & Sig. & 498 & & .055 & .000 & .000 \\
\hline & Pearson Correlation & -.045 & -.103 & 1 & .104 & .103 \\
\hline \multirow[t]{2}{*}{ OCB } & Sig. & .398 & .055 & & .051 & .054 \\
\hline & Pearson Correlation & $.144^{* *}$ & $-.243^{* *}$ & .104 & 1 & $.979^{* *}$ \\
\hline \multirow[t]{2}{*}{ IWE } & Sig. & .007 & .000 & .051 & & .000 \\
\hline & Pearson Correlation & $.130^{*}$ & $-.243^{* *}$ & .103 & $.979^{* *}$ & 1 \\
\hline EL & Sig. & 015 & .000 & .054 & .000 & \\
\hline
\end{tabular}

\subsubsection{Turnover Intention}

\footnotetext{
${ }^{30}$ Mussie Teclemichael Tessema and Joseph L. Soeters, "Challenges and Prospects of HRM in Developing Countries: Testing the HRM-Performance Link in the Eritrean Civil Service," International Journal of Human Resource Management 17, no. 1 (January 2006): 86-105, https://doi.org/10.1080/09585190500366532.
} 
The Scholar Islamic Academic Research Journal

Vol. 6, No. 1 || January -June 2020 || P. 1-23

https://doi.org/10.29370/siarj/issue10ar1

Three item scale of Turnover Intention by Hellgren et al. ${ }^{31}$ has been used. The sample items include; "If I was completely free to choose, I would leave this job" etc. Cronbach's alpha reliability of Turnover Intention scale was 0.986, representing satisfactory measuring reliability.

\section{Table 5: Model Summary}

$\begin{array}{lcccc}\text { Models } & \text { R Square } & \begin{array}{c}\text { Std. Error of } \\ \text { the Estimate }\end{array} & \text { F statistics } & \text { Sig. } \\ \begin{array}{l}\text { (Model 1) } \\ \text { Outcome JP }\end{array} & 0.017 & 0.34928 & 5.967 & .015^{\mathrm{b}} \\ \begin{array}{c}\text { Predictor EL } \\ \text { (Model 2) }\end{array} & & & & \\ \text { Outcome OCB } & 0.011 & 0.39939 & 3.738 & .054^{\mathrm{b}} \\ \begin{array}{c}\text { Predictor EL } \\ \text { (Model 3) }\end{array} & & & \\ \\ \quad\end{array}$

\section{Methods of Data Collection and Analysis}

Data has been analyzed by using SPSS20 (Statistical Package for Social Science) and PROCESS by, Andrew F. Hayes. The analysis and results were centered on

\footnotetext{
31 Johnny Hellgren, Anders Sjoberg, and Magnus Sverke, "Intention to Quit: Effects of Job Satisfaction and Job Perceptions," in Feelings Work in Europe, 1997, 415-23, https://www.academia.edu/download/40604544/C6_Hellgren__Sjoberg__Sverke_1997. pdf.
} 
The Scholar Islamic Academic Research Journal

Vol. 6, No. 1 || January -June 2020 || P. 1-23

https://doi.org/10.29370/siarj/issue10ar1

reliability analysis (internal consistency), mean, standard deviation, correlation analysis and regression analysis.

\subsection{Results}

Table 4 shows the Pearson correlation for all of our interval variables and correlation is significant at the 0.05 level. Pearson correlation coefficient $(r=-$ $0.45, \mathrm{p}>0.05)$ shows that there exist insignificant mutual relationship between two outcome variables that is OCB and JP. Similarly, JP to TI carry insignificant relationship $(\mathrm{r}=.036, \mathrm{p}>0.05)$. Rests of the relationships are significant and these results help us move ahead and conduct a thorough regression analysis which will help us to make important predictions.

\section{Table 6: Coefficients}

\begin{tabular}{|c|c|c|c|c|c|}
\hline \multirow[t]{2}{*}{ Models } & \multicolumn{2}{|c|}{$\begin{array}{c}\text { Unstandardized } \\
\text { Coefficients }\end{array}$} & \multirow{2}{*}{$\begin{array}{c}\text { Standardized } \\
\text { Coefficients } \\
\text { Beta }\end{array}$} & \multirow[b]{2}{*}{$\mathbf{T}$} & \multirow[b]{2}{*}{ Sig. } \\
\hline & B & Std. Error & & & \\
\hline \multirow[t]{2}{*}{ Model 1} & 3.746 & .165 & \multirow[t]{2}{*}{.130} & 22.724 & .000 \\
\hline & .098 & .040 & & 2.443 & .015 \\
\hline Model 2 & $\begin{array}{c}3.559 \\
.088\end{array}$ & $\begin{array}{l}.189 \\
.046\end{array}$ & .103 & $\begin{array}{c}18.880 \\
1.933\end{array}$ & $\begin{array}{l}.000 \\
.054\end{array}$ \\
\hline Model 3 & $\begin{array}{l}3.845 \\
-.480\end{array}$ & $\begin{array}{l}.425 \\
103\end{array}$ & -.243 & $\begin{array}{l}9.054 \\
-4.663\end{array}$ & $\begin{array}{l}.000 \\
.000\end{array}$ \\
\hline
\end{tabular}

\subsection{Regression Analysis}


The Scholar Islamic Academic Research Journal

Vol. 6, No. 1 || January -June 2020 || P. 1-23

https://doi.org/10.29370/siarj/issue10ar1

Since we have three different outcomes i.e.-OCB, JP, TI \& one predictor EL for which we have to analyze the moderating role of IWE, therefore we will develop three different regression based moderation models for which results are presented in the lines ahead.

Table 7: EL to JP relationship with IWE as Moderator

\begin{tabular}{lllllll}
\hline \multicolumn{1}{c}{ R } & \multicolumn{1}{c}{ R-sq } & MSE & \multicolumn{1}{c}{ F } & \multicolumn{1}{c}{ df1 } & \multicolumn{1}{c}{ df2 } & P \\
\hline \multicolumn{1}{c}{0.1858} & 0.0345 & 0.1205 & 3.6096 & 3.0000 & 346.0000 & 0.0136 \\
Model & & & & & & \\
& coeff & Se & $\mathbf{t}$ & $\mathbf{p}$ & LLCI & ULCI \\
constant & 4.1246 & 0.0207 & 198.8893 & 0.0000 & 4.0838 & 4.1654 \\
IWE & 0.3100 & 0.2074 & 1.4946 & 0.1359 & -0.0980 & 0.7180 \\
EL & -0.0380 & 0.2117 & -0.1794 & 0.8578 & -0.4543 & 0.3784 \\
int_1 & 0.1112 & 0.0560 & 1.9866 & 0.0478 & 0.0011 & 0.2214 \\
\hline
\end{tabular}

Note: Product terms key: int_l $E L \quad X \quad I W E$

\begin{tabular}{|llllll}
\multicolumn{6}{|c}{ R-square increase due to interaction(s): } \\
\multicolumn{1}{|c|}{ R2-chng } & F & df1 & df2 & p \\
int_1 & 0.0104 & 3.9466 & 1.0000 & 346.0000 & 0.0478 \\
\hline
\end{tabular}

\begin{tabular}{|c|c|c|c|c|c|c|}
\hline \multicolumn{7}{|c|}{ Conditional effect of $\mathrm{X}$ on $\mathrm{Y}$ at values of the moderator(s): } \\
\hline IWE & Effect & se & $\mathrm{t}$ & $\mathrm{P}$ & LLCI & ULCI \\
\hline-0.430 & -0.0858 & 0.2032 & -0.4220 & 0.6733 & -0.4855 & 0.3139 \\
\hline 0.000 & -0.0380 & 0.2117 & -0.1794 & 0.8578 & -0.4543 & 0.3784 \\
\hline 0.430 & 0.0098 & 0.2224 & 0.0441 & 0.9648 & -0.4277 & 0.4473 \\
\hline
\end{tabular}

As shown in Tables $5 \&$ 6, that involves JP as outcome and EL as predictor, $\mathrm{R}^{2}=$ 0.017 with $\mathrm{p}<0.05$ explains $1 \%$ variation in the outcome variable due to the model. In model 2, the EL regresses the OCB with $\mathrm{R}^{2}=0.011$ with $\mathrm{p}<0.05$ that indicates that this model also explains $1 \%$ variation in the outcome variable. In model 3, EL regresses the outcome TI at $\mathrm{R}^{2}=0.059$ with $\mathrm{p}<0.05$ that indicates that the model explains $5 \%$ variation in the outcome variable. 
The Scholar Islamic Academic Research Journal

Vol. 6, No. 1 || January -June 2020 || P. 1-23

https://doi.org/10.29370/siarj/issue10ar1

The value of coefficient $(\beta=.098, \mathrm{p}<0.05)$ indicates there is sufficient evidence to state that EL predicts JP. Similarly $(\beta=.088, p<0.05)$ and $(\beta=-0.480, p<$ 0.05 ) indicates that EL predicts OCB and TI. Therefore, in all these three cases, EL significantly predicts the JP and OCB and TI.

\subsection{Moderation}

We have followed the process by Andrew F. Hayes (2013) - Introduction to Mediation, Moderation \& conditional process analysis: A regression based approach. We have also included in our analysis Johnson Nayman Technique which informs us about what range of the moderator, the effect of predictor is significantly positive, non-significant or significantly negative.

This is also evident from marginal $R^{2}$ increase due to interaction $\left(R^{2}=.0104, p>\right.$ 0.05) (Please See Table 7). Moreover, for moderation to occur the confidence interval should not include 0 . In our case, the lower level of confidence interval (LLCI) \& upper level of confidence interval (ULCI) does not include 0 . So the $\beta$ $=.1112$ in the population is not likely to be 0 , putting it simply, there is slight moderation effect detected in the population.

Now we look at the conditional effect of X (EL) on Y (JP) at various values of the moderator. We

have three Fig 2: SCATTERPOLOT: EL with JP by IWE

different values for moderator (IWE), here $\quad 0.4295$ represents the upper level of (IWE) which is one standard deviation above

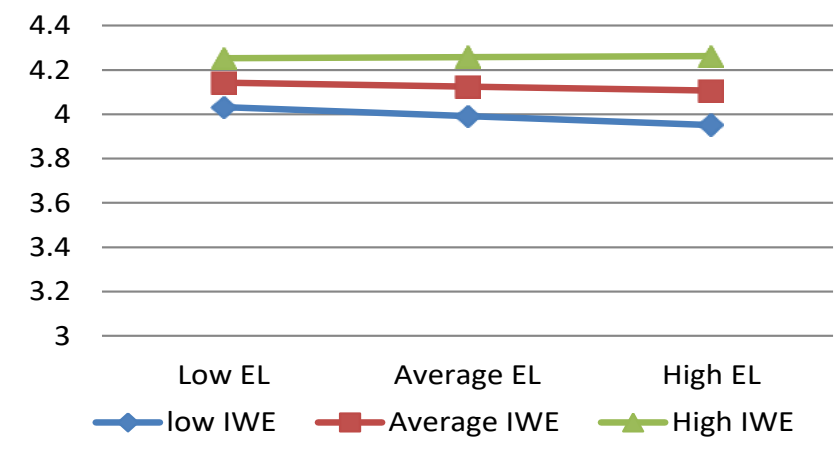


The Scholar Islamic Academic Research Journal

Vol. 6, No. 1 || January -June 2020 || P. 1-23

https://doi.org/10.29370/siarj/issue10ar1

the mean while the value -0.4295 represents lower level of (IWE)--i.e., one standard deviation below the mean. Under the heading of effect, the value -.0858 shows the effect of EL on JP at low level of IWE \& this effect appears insignificant at $\mathrm{p}>0.05$. At the average \& high level of IWE -.0380 and .0098 this effect remains insignificant as well with p>0.05 (Please See Fig 2 and Table 7). On the whole, keeping in view, the overall statistics we suggest that there is no significant moderation that exists in this case and therefore, we reject the hypothesis that Islamic work ethics moderates the relationship between ethical leadership and job performance.

Table 8: EL to OCB relationship with IWE as a Moderator

\begin{tabular}{lllllll} 
R & R-sq & MSE & F & df1 & df2 & P \\
\hline 0.1051 & 0.0111 & 0.1604 & 1.0349 & 3.0000 & 346.0000 & 0.3771
\end{tabular}

\begin{tabular}{|c|c|c|c|c|c|c|}
\hline Model & coeff & se & $\mathbf{t}$ & p & LLCI & ULCI \\
\hline constant & 3.9182 & 0.0287 & 136.6578 & 0.0000 & 3.8619 & 3.9746 \\
\hline IWE & 0.0717 & 0.2738 & 0.2619 & 0.7936 & -0.4668 & 0.6103 \\
\hline EL & 0.0435 & 0.3052 & 0.1426 & 0.8867 & -0.5567 & 0.6438 \\
\hline int_1 & 0.0153 & 0.1105 & 0.1385 & 0.8900 & -0.2020 & 0.2326 \\
\hline
\end{tabular}

R-square increase due to interaction(s):

\begin{tabular}{|c|c|c|c|c|c|c|}
\hline int_1 & $\begin{array}{l}\text { R2-chng } \\
0.0002\end{array}$ & $\begin{array}{l}\text { F } \\
0.0192\end{array}$ & $\begin{array}{l}\text { df1 } \\
1.0000\end{array}$ & $\begin{array}{l}\text { df2 } \\
346.0000\end{array}$ & $\begin{array}{l}\mathrm{P} \\
0.8900\end{array}$ & \\
\hline \multicolumn{7}{|c|}{ Conditional effect of $\mathrm{X}$ on $\mathrm{Y}$ at values of the moderator(s): } \\
\hline IWE & Effect & se & $\mathbf{t}$ & $\mathbf{p}$ & LLCI & ULCI \\
\hline-0.4295 & -0.0858 & 0.2032 & -0.4220 & 0.6733 & -0.4855 & 0.3139 \\
\hline 0.0000 & 0.0435 & 0.3052 & 0.1426 & 0.8867 & -0.5567 & 0.6438 \\
\hline 0.4295 & 0.0501 & 0.3371 & 0.1486 & 0.8819 & -0.6129 & 0.7131 \\
\hline
\end{tabular}

The fifth null hypothesis, as shown in Table 8 , for interaction term $(\beta=0.153$, $\mathrm{p}>0.05)\left(\mathrm{R}^{2}=.0002, \mathrm{p}>0.05\right)$ and $\beta=.0153$ in the population is likely to be 0 thus 
The Scholar Islamic Academic Research Journal

Vol. 6, No. 1 || January -June 2020 || P. 1-23

https://doi.org/10.29370/siarj/issue10ar1

no moderation effect has been detected in the population and thus this hypothesis is rejected.

Table 9: EL to TI relationship with IWE as a Moderator

\begin{tabular}{lllllll} 
R & R-sq & MSE & F & df1 & df2 & p \\
\hline 2530 & 0.0640 & 0.8096 & 2.3469 & 3.0000 & 346.00 & 0.0725
\end{tabular}

\begin{tabular}{lcccccr} 
Model & & & & & & \\
& coeff & se & t & p & LLCI & ULCI \\
\hline constant & 1.8391 & 0.0666 & 27.6024 & 0.0000 & 1.7081 & 1.9702 \\
IWE & -0.3305 & 0.6226 & -0.5309 & 0.5959 & -1.5551 & 0.8941 \\
EL & 0.0662 & 0.7422 & 0.0892 & 0.9290 & -1.3937 & 1.5261 \\
int_1 & 0.1937 & 0.2910 & 0.6655 & 0.5062 & -0.3787 & 0.7661
\end{tabular}

Product terms key: int_l EL $\quad X \quad I W E$

\begin{tabular}{llllll}
\multicolumn{6}{l}{ R-square increase due to interaction(s): } \\
& R2-chng & F & df1 & df2 & P \\
\hline int_1 & 0.0045 & 0.4429 & 1.0000 & 346.0000 & 0.5062
\end{tabular}

\begin{tabular}{|c|c|c|c|c|c|c|}
\hline \multicolumn{7}{|c|}{ Conditional effect of $\mathrm{X}$ on $\mathrm{Y}$ at values of the moderator(s): } \\
\hline IWE & Effect & se & $\mathbf{t}$ & $\mathbf{p}$ & LLCI & ULCI \\
\hline-0.4295 & -0.0170 & 0.6702 & -0.0254 & 0.9798 & -1.3352 & 1.3012 \\
\hline 0.0000 & 0.0662 & 0.7422 & 0.0892 & 0.9290 & -1.3937 & 1.5261 \\
\hline 0.4295 & 0.1494 & 0.8270 & 0.1806 & 0.8568 & -1.4772 & 1.7759 \\
\hline
\end{tabular}

Looking at the conditional effect of $\mathrm{X}(\mathrm{EL})$ on $\mathrm{Y}(\mathrm{OCB})$

Fig 3: SCATTERPLOT: EL with OCB by IWE

(Please See Table 8 and Fig 3), we also see that no moderation effect has been seen in this case and we can

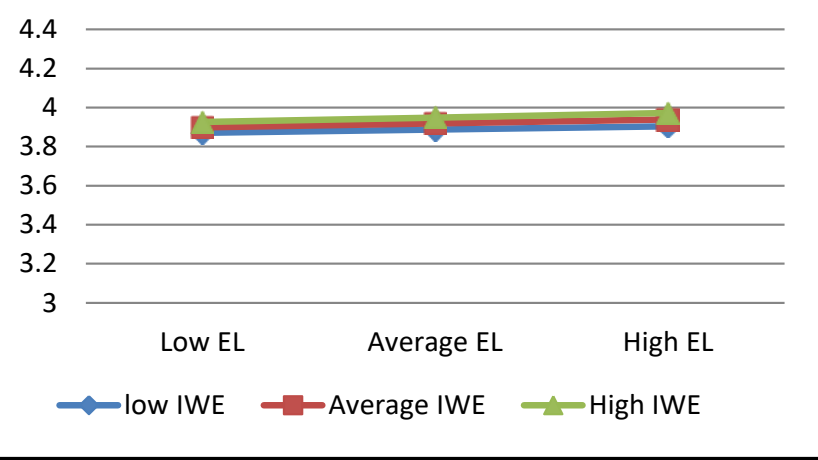


The Scholar Islamic Academic Research Journal

Vol. 6, No. 1 || January -June 2020 || P. 1-23

https://doi.org/10.29370/siarj/issue10ar1

safely suggest that IWE does not moderate the relationship between Ethical Leadership \& Organization Citizenship Behavior.

For Sixth null hypothesis we have $(\beta=.1937, p>0.05)$ therefore we infer that no moderation has occurred in this case as well. This is also evident from $\mathrm{R}^{2}$ increase due to interaction where there is small change in $\mathrm{R}^{2}=.0045$ with insignificant value of $p>0.05$, thus pointing towards the fact that no moderation exists. Here we again see that LLCI \& ULCI include 0 . So the $\beta=.1937$ in the population is likely to be 0 .

Conditional effect of $\mathrm{X}$

(EL) on $\mathrm{Y}(\mathrm{TI})$ at the

Fig 4: SCATTERPLOT: EL WITH TI by IWE.

three different values

for moderator (IWE),

shows the similar

results (Please See

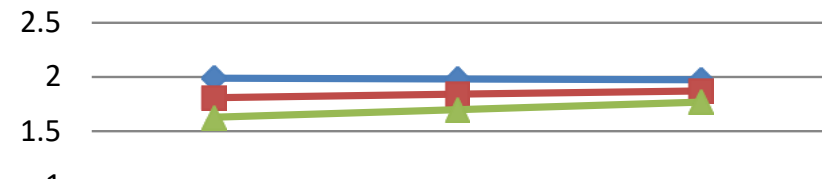

Table 9 and Fig 4).

Values at various

levels of standard

deviation remain

0.5

insignificant, therefore, we reject the hypothesis that suggests that IWE moderates the relationship between EL and TI.

\section{Discussion}

Ethical Leadership is of utmost importance for effective human resource management. Its importance multiplies because of the positive role that such leaders play in increasing the organizational performance. As suggested above, employee's attitudes and behaviors which are direct result of leader's capability can be measured through variety of factors such as employee's job performance, 
The Scholar Islamic Academic Research Journal

Vol. 6, No. 1 || January -June 2020 || P. 1-23

https://doi.org/10.29370/siarj/issue10ar1

job involvement, job satisfaction, organizational citizenship behavior, and organizational commitment ${ }^{32}$. It is suggested that ethical leadership develops an environment of trust and commitment of employees, which in turn leads to long term performance of the organization and better job outcomes.

Moreover, ethics are considered an important component of organizational culture, it may not be useful to implement the same ethical code across cultures. Therefore, parallel to western ethics, scholars have presented ethics from Islamic perspectives. Islamic Work Ethics constitute a variable that should be examined with respect to variety of job outcomes. Notwithstanding the importance of Islamic work ethics, efforts to examine the moderating effects of Islamic Work Ethics between job outcomes and ethical leadership have remained scarce. This study contributes by filling this gap. Results of our study show that strong relationship between Ethical Leadership and job outcomes is not moderated in all cases by Islamic Work Ethics. We agree to Ali ${ }^{33}$ and Abbasi et al. ${ }^{34}$ that Islamic work ethics may influence employee's jobs outcomes but the relationship between ethical leader and job outcomes itself is so stronger that context may not essentially effect it.

Our research carries some limitations. Firstly, our work involves static analysis while a longitudinal research grounded in equilibrium analysis is needed to understand these relationships. Moreover, we recommend future research involving predictive models based on similar testing with some alteration, such as other rating instruments. Additionally, an extended population sample that is not restricted in telecom sector or one country may also bring new light to this phenomenon. Future research involving ethical leadership and Islamic work ethics might look at the intervening variables such as Culture. Furthermore, future endeavors may consider to study the moderating role of Islamic Work

\footnotetext{
${ }^{32}$ McShane, Steven L and Von Glinow, "Workplace Emotions, Attitudes, and Stress."

${ }^{33}$ Ali, "The Islamic Work Ethic in Arabia."

34 Abbasi, Rehman, and Bibi, "Islamic Work Ethics: How It Affects Business Performance."
} 
The Scholar Islamic Academic Research Journal

Vol. 6, No. 1 || January -June 2020 || P. 1-23

https://doi.org/10.29370/siarj/issue10ar1

Ethics on other important work-related attitudes and behaviors such as creativity, work engagement, and deviant behaviors.

The finding of this research has essential managerial implications. Ongoing economic downturn \& higher turnover compels the leaders and managers to find out ways to improve subordinate motivation \& gain performance for the organization. Our research suggests that managers in telecom sector should develop ethical leadership to associate with positive employee's outcome which is ultimate beneficial for the success of the organization. Practical evidence of the study is that ethical leadership minimizes the turnover intention problem. Moreover, human resource departments of the telecom sector needs to learn, plan, execute and monitor Islamic ethics based human resource practices that involve ethical recruitment and selection, training and compensation activities.

\subsection{Conclusion}

This study found significant positive relationship of ethical leadership with job performance and organizational citizenship behavior \& significant negative relationship between Ethical Leadership and Turnover Intention. Our findings also confirm that Islamic work ethics moderates the relationship of ethical leadership and job performance. It has been suggested that managers should learn to improve communication of ethical values and guidelines, encourage ethical practices with the relation of Islamic work ethics to improve the subordinates' job performance. We also suggest that since organization's deal with variety of stakeholders - customer, employees, stakeholders \& shareholders, organizations adopt their norms \& values so as to be considered legitimate in the eyes of these constituents. Therefore, in this exchange of values and norms employees display the code of ethics that can help them present legitimating account of their activities to various constituents, ethical leadership is crucial in this process.

\section{(C) (1)(0)}

BY NC SA This work is licensed under a Creative Commons Attribution-NonCommercial-ShareAlike 4.0 International (CC BY-NC-SA 4.0) 